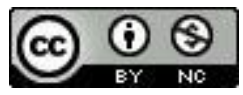

Jurnal Pendidikan Matematika Indonesia is licensed under

A Creative Commons Attribution-Non Commercial 4.0 International License.

\title{
Analisis Kesalahan Siswa dalam Menyelesaikan Soal Logaritma
}

\author{
Ong, Florencia Ivani Hananta ${ }^{1)}$, Novisita Ratu ${ }^{2)}$ \\ ${ }^{1)}$ Universitas Kristen Satya Wacana, Salatiga, Indonesia \\ E-mail:202014001@student.uksw.edu \\ ${ }^{2)}$ Universitas Kristen Satya Wacana, Salatiga, Indonesia \\ E-mail: novisita.ratu@staff.uksw.edu
}

\begin{abstract}
Abstrak. Penelitian ini bertujuan untuk mengetahui kesalahan-kesalahan yang dilakukan siswa dalam mengerjakan soal logaritma. Penelitian ini adalah penelitian kualitatif dengan teknik purposive sampling. Subjek pada penelitian ini yaitu 3 siswa SMA kelas X. Analisis kesalahan ini menggunakan teori dari Kastolan. Berdasarkan penelitian ditemukan kesalahan-kesalahan yang dilakukan oleh siswa adalah karena siswa tidak memahami soal yang ada, tidak memahami konsep materi seperti sifat-sifat logaritma, tidak memakai semua data yang ada pada soal bahkan kadang melewatkan data yang penting, ketidaktelitian dan ketidakcermatan saat menghitung karena mengerjakan secara langsung tanpa menggunakan langkah-langkah pengerjaan tetapi ada juga yang menggunakan langkah-langkah dan masih salah karena tidak teliti. Contohnya pada soal perkalian logaritma, ada subjek yang langsung mengerjakan tanpa menggunakan cara, jawabannya hanya kurang tanda minus saja akibat tidak menjabarkan dan menggunakan langkah pengerjaan. Kemudian tidak paham sifat logaritma mana yang harus dipakai dan kekeliruan penggunaan sifat logaritma akibat tidak hafal sifat-sifat logaritma. Contohnya semua subjek tidak tahu akan sifat logaritma yaitu $a^{a} \log b=b$ padahal jika subjek mengetahui sifat tersebut maka jawabannya akan sangat mudah dan tidak terjadi kesalahan.
\end{abstract}

Kata Kunci: logaritma, analisis kesalahan, Kastolan

\section{Pendahuluan}

Matematika merupakan pelajaran yang sangat penting yang diajarkan di sekolah karena dapat mengembangkan kemampuan berpikir siswa untuk menganalisis sebuah permasalahan secara kritis. Matematika juga mempersiapkan siswa untuk menghadapi kehidupan yang selalu berkembang sehingga dapat berpikir secara rasional, efektif, dan efisien. Matematika bukan hanya ilmu berhitung saja melainkan juga ilmu yang mempelajari pola dan hubungan, menemukan dan memecahkan suatu masalah (Riedesel 1996:170). Menurut Widodo pemecahan masalah dalam matematika sangat penting karena siswa akan mempelajari suatu konsep dan juga prinsip dalam matematika dan dapat diaplikasikan dalam memecahkan masalah (2013: 106). Matematika selalu menjadi pelajaran yang paling ditakuti oleh siswa dibandingkan dengan pelajaran-pelajaran lain (Alper Ciltas and
Enver Tatar, 2011). Siswa sering melakukan kesalahan dalam memahami persoalan matematika ataupun saat mengerjakan persoalan Matematika. Kesulitan siswa terlihat dari kesalahan yang berbentuk kesalahan konsep, berhitung, pemahaman, dan cara berpikir logis serta matematis dalam menyelesaikan soal-soal matematika. Mulyadi (2010: 6) berpendapat bahwa kesulitan belajar disebabkan karena adanya hambatan dalam belajar sehingga tidak dapat mencapai tujuan dan dapat diatasi dengan usaha yang lebih giat.

Tujuan pembelajaran matematika dapat dilihat berhasil atau tidaknya dari keberhasilan siswa dalam memahami konsep dan pengaplikasiannya dalam kehidupan sehari-hari. Diperlukan tes atau ujian untuk mengetahui kemampuan siswa dan kesalahan-kesalahan siswa dalam mengerjakan soal. Kesalahan ada dua jenis yaitu yang bersifat 
sistematis dan yang bersifat konsisten dipengaruhi oleh kompetensi siswa, sedangkan yang bersifat insidental tidak dipengaruhi oleh kompetensi siswa (Amir, 2015).Sebenarnya, kesalahan adalah hal yang wajar yang dilakukan oleh siswa. Namun bila kesalahan yang dilakukan banyak dan berkelanjutan maka diperlukan penanganan khusus karena jika tidak segera diberi penanganan khusus maka akan berdampak buruk bagi siswa. Mengingat materi matematika saling berhubungan dengan materi selanjutnya. Menurut Radatz dalam Blanco \& Garrote (2007) kesalahan siswa adalah hasil dari pembelajaran dari pengalaman pembelajaran pada materi sebelumnya. Setiap siswa dalam menyelesaikan masalah matematika harus melalui lima langkah, yaitu membaca, memahami, transformasi, keterampilan proses, dan penentuan jawaban akhir (Newman, 1977).

Hasil penelitian Ni Nyoman Yuni Darjiani dkk (2015) menyatakan rata-rata siswa yang melakukan kesalahan dalam pengerjaan soal adalah 49,25\%, dengan kesalahan yang paling sering adalah kesalahan dalam pemahaman konsep yaitu $8,65 \%$, kesalahan dalam pemecahan masalah 7,26 persen, kesalahan dalam 2 aspek sekaligus yaitu konsep dan keterampilan berhitung 4,93\%, kesalahan dalam pemecahan masalah dan keterampilan berhitung $4,70 \%$, kesalahan dalam keterampilan berhitung yaitu $14,23 \%$, kesalahan dalam pemahaman konsep dan pemecahan masalah $0,90 \%$, dan kesalahan dalam tiga aspek yaitu pemahaman konsep, keterampilan berhitung, dan pemecahan masalah adalah $8,37 \%$.

Hasil penelitian Septianingrum (2017) menyatakan bahwa kerangka analisis dikembangkan berdasarkan tiga kategori kesulitan yaitu kesulitan membaca dan bahasa, pemahaman konsep, dan perhitungan. Kesulitan-kesulitan tersebut yang akhirnya menyebabkan siswa melakukan kesalahan dalam pengerjaan soal matematika. Kesalahannya secara umum yaitu siswa tidak dapat memahami soal dengan baik, siswa tidak memahami konsep yang digunakan pada soal, dan siswa keliru dalam menghitung jawaban. Serta pemahaman dan kreativitas siswa yang rendah dalam mengidentifikasi permasalahan nyata ke dalam model matematika. Menurut Istiyanto dalam Uni (2009) dalam mengerjakan soal matematika, kesalahan yang sering dilakukan adalah siswa hanya menghafalkan soal-soal dan rumus-rumus matematika bukannya latihan mengerjakan soal matematika. Menurut Kastolan (1992) kesalahan siswa ada tiga yaitu kesalahan konsep, kesalahan prosedur dalam menentukan langkah-langah yang diambil, dan kesalahan teknik atau tidak teliti dalam mengerjakan. Kebanyakan siswa melakukan kesalahan dalam ketiga aspek yang disebutkan oleh Kastolan, namun ada juga siswa yang melakukan kesalahan karena malas. Contohnya, malas menghitung, malas membaca soal, malas mengerjakan soal, dll. Kemalasan ini sebagian besar diawali dari siswa yang tidak paham akan konsep pada bab yang diajarkan. Faktor yang menimbulkan kesalahan pada siswa ada dua yaitu faktor internal misalnya kecerdasan, sikap dan kebiasaan yang salah dalam mempelajari sesuatu, dan faktor eksternal misalnya tempat belajar, cuaca, suasana, dll (Ishak dan Warji, 1987).

Materi logaritma dianggap cocok untuk penelitian ini karena logaritma memiliki banyak sifat yang harus dipahami oleh siswa sehingga dapat dengan mudah menemukan kesalahan siswa. Tidak paham akan sifat logaritma termasuk kedalam ketidakpahaman konsep. Dalam satu soal logaritma harus dikerjakan dengan minimal satu sifat, kebanyakan soal logaritma dikerjakan dengan banyak sifat. Siswa harus benar-benar paham dengan sifat logaritma agar tidak terjadi kesalahan jawaban. Siswa salah dalam menggunakan sifatpun akan sangat berpengaruh dengan hasil jawaban yang didapat. Langkah-langkah dalam mengerjakan logaritma juga termasuk hal yang penting karena banyak siswa yang mengerjakan tanpa menggunakan langkah-langkah pengerjaan kemudian melakukan kesalahan akibat tidak teliti. Oleh sebab itulah dilakukan penelitian ini untuk mengetahui kesalahan siswa dalam mengerjakan soal-soal logaritma.

\section{Metode}

Penelitian ini adalah penelitian kualitatif dengan Teknik pengumpulan data yaitu 1) tes diberikan untuk mendapatkan data yaitu hasil pekerjaan siswa, 2) wawancara dilakukan untuk mengetahui pemahaman-pemahaman siswa mengenai soal dan 
jawaban yang mereka kerjakan serta untuk memperkuat hasil data dari tes tertulis, 3) dokumentasi hasil jawaban siswa serta pengumpulan data dan nilai siswa. Penelitian kualitatif adalah penelitian yang dilakukan dengan objek alamiah yang berkembang apa adanya tidak dimanipulatif oleh peneliti (Sugiyono, 2014). Penelitian ini menggunakan teknik purposive sampling yaitu menetapkan ciri khusus dalam pengambilan subjek sehingga dapat memenuhi penelitian.

\section{Hasil dan Pembahasan}

Peneliti memberikan tes tentang logaritma kepada 3 orang siswa kelas X. Berdasarkan hasil penelitian, subjek A melakukan kesalahan pada 5 soal, subjek B melakukan kesalahan pada 3 soal dan subjek C melakukan kesalahan pada 2 soal dari 6 soal yang diberikan.

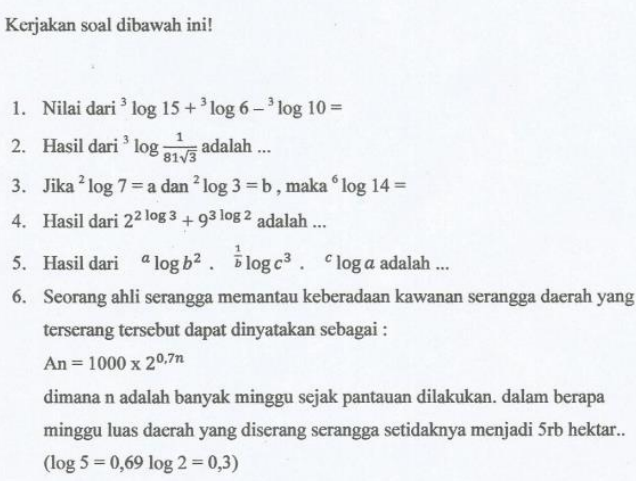

Gambar 1. Soal penelitian yang diberikan pada subjek

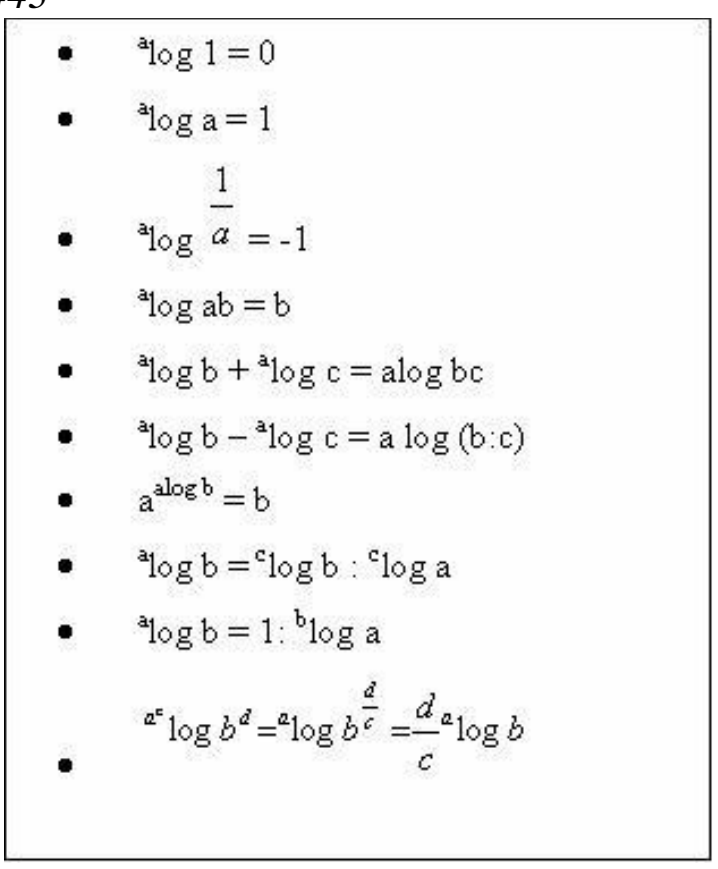

Gambar 2. Sifat logaritma

Berikut adalah pembahasan dari kesalahan-kesalahan yang dilakukan oleh subjek dalam mengerjakan soal logaritma.

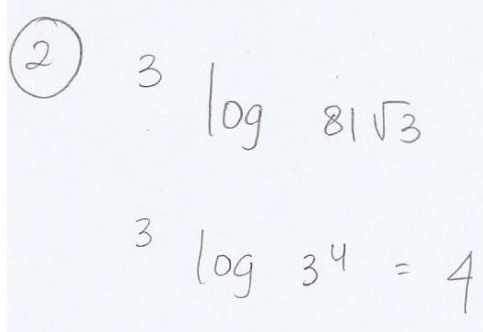

Gambar 3. Kesalahan subjek A pada soal no. 2

Pada Gambar 3 subjek A melakukan kesalahan karena ketidakcermatan dalam melakukan operasi hitung Subjek A juga tidak mampu mengartikan bahasa matematika karena seharusnya pada soal yang tertera adalah ${ }^{3} \log \frac{1}{81 \sqrt{3}}$ tapi subjek A mengerjakan langsung ${ }^{3} \log 81 \sqrt{3}$, dilanjutkan dengan perhitungan yang salah yaitu ${ }^{3} \log 3^{4}$. Subjek A tidak memperhitungkan adanya $\sqrt{3}$ yang harusnya menjadi $3^{\frac{1}{2}}$. 


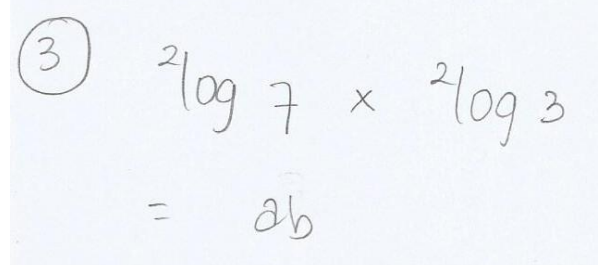

Gambar 4. Kesalahan subjek A pada soal no. 3

Pada Gambar 4 subjek A melakukan kesalahan karena tidak menguasai konsep dengan benar, tidak mampu menggunakan data, dan tidak mampu menarik kesimpulan. ${ }^{2} \log 7=$ a dan ${ }^{2} \log 3=$ b yang seharusnya adalah data yang diketahui di soal, menjadi jawaban dan dikalikan. Padahal pertanyaan yang sesungguhnya adalah ${ }^{6} \log 14$ yang kemudian menjadi $\frac{{ }^{2} \log 14}{{ }^{2} \log 6}$ kemudian dijabarkan menjadi $\frac{{ }^{2} \log 7.2}{{ }^{2} \log 3.2}$. Setelah itu dijadikan kedalam bentuk $\frac{{ }^{2} \log 7+{ }^{2} \log 2}{{ }^{2} \log 3+{ }^{2} \log 2} . \quad$ Kemudian hasil tersebut dimasukkan pada data yang ada di soal yaitu menjadi $\frac{a+1}{b+1}$ Saat ditanya, subjek A menjawab memang tidak memahami soalnya dan tidak bisa mengerjakan soal nomor 3 .

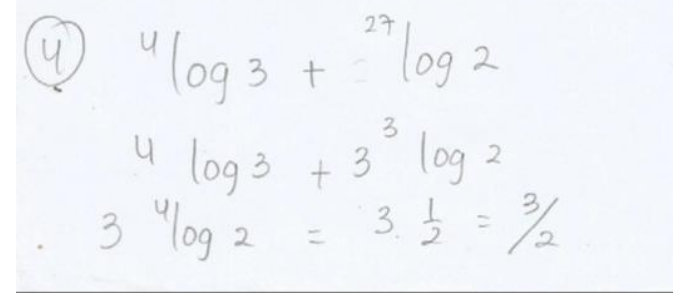

Gambar 5. Kesalahan subjek A pada soal no. 4

Pada Gambar 5 subjek A melakukan kesalahan karena tidak memahami sifat logaritma. Saat ditanyai subjek juga mengakui bahwa dia tidak hafal dengan sifat logaritma dan tidak memahami sifat-sifat logaritma, yang dia ketahui hanya sifat logaritma yang penjumlahan dan pengurangan saja.

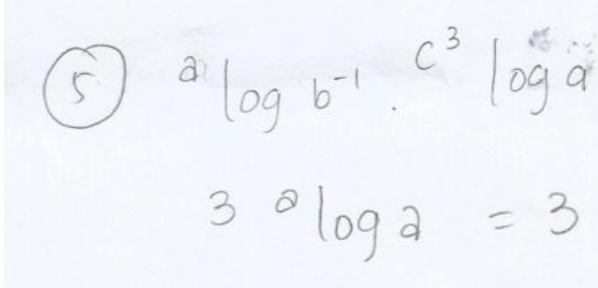

Gambar 6. Kesalahan subjek A pada soal no. 5

Pada Gambar 6 subjek A tidak cermat dalam melakukan operasi hitung. Tidak menggunakan cara yang step by step dan langsung menuliskan jawaban bisa menjadi salah satu kesalahan subjek A tidak cermat dalam mengerjakan soal. Seharusnya subjek menjabarkan $2^{a} \log b \cdot \frac{3}{-1} \quad{ }^{b} \log c \quad . \quad{ }^{c} \log a$ agar tidak salah langkah. Jawaban subjek hampir benar, subjek menjadi salah karena tidak mengikuti langkah-langkah yang benar dan melupakan -1 yang seharusnya dikalikan dengan 3 lalu jawabannya adalah -3 .

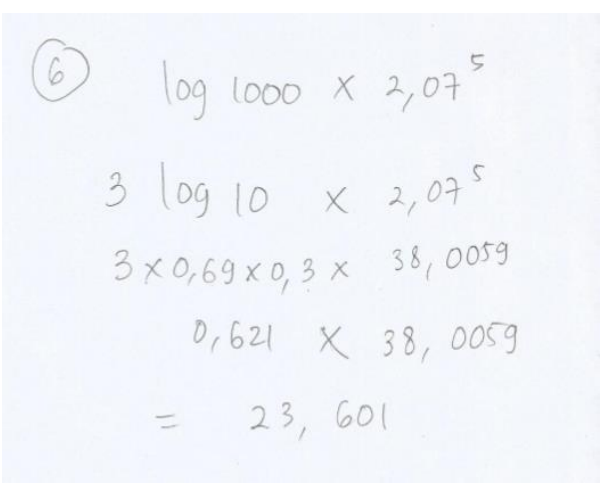

Gambar 7. Kesalahan subjek A pada soal no. 6

Pada Gambar 7 subjek A tidak memahami maksud dari soal yang dikerjakan dan tidak menggunakan informasi penting dari soal yang menyebutkan 5rb hektar.

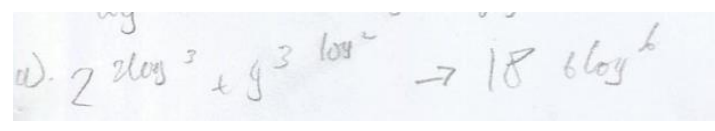

Gambar 8. Kesalahan subjek B pada soal no. 4

Pada Gambar 8 subjek B melakukan kesalahan karena tidak memahami sifat logaritma yaitu 
$a^{a} \log b=b$. Subjek hanya mengkalikan kedua bentuk logaritma tersebut dan menjadi 18 ${ }^{6} \log 6$. Padahal pada soal sudah jelas tertulis tambah tetapi subjek menyelesaikan dengan asal dikalikalikan saja. Hal itu terjadi karena subjek sangat tidak paham dengan bentuk soal dan juga tidak paham dengan sifat logaritma. Subjek juga cenderung malas menghitung dan malas mengerjakan karena ketidakpahamannya tentang sifat logaritma yang telah disebutkan diatas.

Gambar 9. Kesalahan subjek B pada soal no. 5

Pada Gambar 9 subjek B melakukan kesalahan karena ketidakcermatan dalam melakukan operasi hitung.

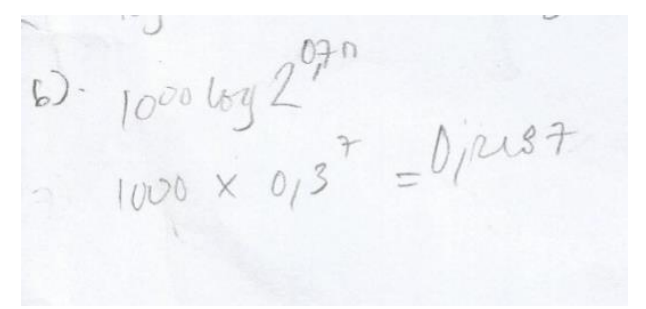

Gambar 10. Kesalahan subjek B pada soal no. 6

Pada Gambar 10 subjek B melakukan kesalahan karena tidak paham dengan soal dan mengabaikan informasi penting pada soal yaitu 5 ribu hektar. Subjek B hanya menjawab dengan mengkalikan angka yang sudah ada pada soal. Petunjuk $\log 5=$ 0,69 dan $\log 2=0,3$ yang seharusnya menjadi petunjuk penting dalam mengerjakan soal juga tidak digunakan oleh subjek B.

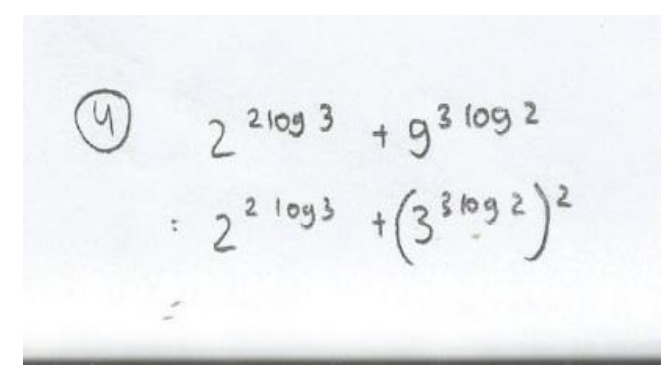

Gambar 11. Kesalahan subjek C pada soal no. 4

Pada Gambar 11 subjek C berhenti mengerjakan ditengah jalan karena tidak memahami sifat logaritma $a^{a} \log b=b$. Subjek $\mathrm{C}$ sudah mengambil langkah yang tepat yaitu menjabarkan $9^{3} \log 2=\left(3^{3} \log 2\right){ }^{2}$. Itu adalah langkah yang sangat bagus akan tetapi langkahnya terhenti karena bentuk itu harus diubah dengan sifat logaritma yang subjek tidak hafalkan.

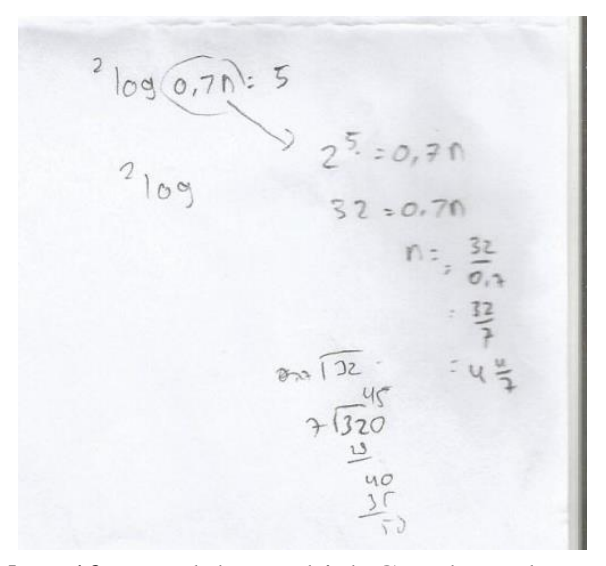

Gambar 12. Kesalahan subjek C pada soal no. 6

Pada Gambar 12 subjek C sudah menggunakan semua informasi yang ada di soal. Pada langkah pertama $1000 \quad \mathrm{x} \quad 2^{0,7 n}=5000, \quad$ subjek menggunakan cara langsung menjadi $2^{0,7 n}=5$. Kemudian subjek berhenti disitu karena tidak paham lagi harus bagaimana melanjutkannya. Seharusnya setelah itu langkahnya adalah mengubah $\log 5=\log 2^{0,7 n}$. Subjek melupakan petunjuk penting pada soal yaitu log 5 $=0,69$ dan $\log 2=0,3$. Apabila subjek bisa melanjutkan sampai pada bentuk log dan melihat 
petunjuknya, maka kemungkinan besar jawaban subjek akan benar. Berikut tabel analisis kesalahan dari subjek A, B, dan C.

TABLE I

Tabel kesalahan ketiga subjek.

\begin{tabular}{|c|c|c|c|}
\hline & Subjek A & Subjek B & Subjek C \\
\hline Soal 1 & $\sqrt{ }$ & $\sqrt{ }$ & $\sqrt{ }$ \\
\hline Soal 2 & $\begin{array}{l}\text { Tidak teliti, } \\
\text { kesalahan } \\
\text { dalam bahasa } \\
\text { matematika }\end{array}$ & $\sqrt{ }$ & $\sqrt{ }$ \\
\hline Soal 3 & $\begin{array}{l}\text { Tidak paham } \\
\text { soal }\end{array}$ & $\sqrt{ }$ & $\sqrt{ }$ \\
\hline Soal 4 & $\begin{array}{l}\text { Tidak paham } \\
\text { sifat } \log \\
a^{a} \log b=b\end{array}$ & $\begin{array}{l}\text { Tidak } \\
\text { paham sifat } \\
\log \\
a^{a} \log b= \\
b\end{array}$ & $\begin{array}{l}\text { Tidak } \\
\text { paham sifat } \\
\log \\
a^{a} \log b= \\
b\end{array}$ \\
\hline Soal 5 & $\begin{array}{l}\text { Tidak } \\
\text { menggunakan } \\
\text { langkah- } \\
\text { langkah, } \\
\text { kurang teliti }\end{array}$ & Kurang teliti & $\sqrt{ }$ \\
\hline Soal 6 & $\begin{array}{l}\text { Tidak paham } \\
\text { soal, } \\
\text { melupakan } \\
\text { data penting } \\
\text { pada soal. }\end{array}$ & $\begin{array}{l}\text { Tidak paham } \\
\text { soal, } \\
\text { melupakan } \\
\text { data penting } \\
\text { pada soal. }\end{array}$ & $\begin{array}{l}\text { Tidak } \\
\text { paham soal. }\end{array}$ \\
\hline
\end{tabular}

Menurut pembahasan dari tabel yang telah tertera, dapat dilihat semua subjek dapat menjawab dengan benar soal nomor 1 . Subjek telah paham betul dengan perhitungan mudah mengenai logaritma, penjumlahan dan pengurangan logaritma. Subjek juga sudah memahami sifat logaritma yaitu $\quad{ }^{a} \log a=1, \quad{ }^{a} \log b+$ ${ }^{a} \log c={ }^{a} \log b . c \quad$ dan $\quad{ }^{a} \log b-$ ${ }^{a} \log c={ }^{a} \log \frac{b}{c}$. Pada soal nomor 2, subjek B dan $\mathrm{C}$ telah menjawab dengan benar. Mereka sudah mengingat pada materi-materi yang telah lalu bahwa $\frac{1}{81 \sqrt{3}}$ dapat berubah menjadi $\frac{1}{3^{\frac{9}{2}}}$ yang kemudian diubah menjadi $3^{-\frac{9}{2}}$. Mereka juga sudah paham bahwa $\sqrt{3}=3^{\frac{1}{2}}$. Seharusnya pengetahuan tentang akar pangkat dan kuadrat siswa sudah paham dan tidak melakukan kesalahan karena materi tersebut bukanlah materi yang baru-baru diajarkan dan sering dipakai dalam banyak materi matematika dan pengaplikasian kehidupan seharihari Kemudian pada soal nomor 3 subjek B dan C dapat menjawab lagi dengan benar, yang artinya mereka paham dengan soal permisalan ${ }^{2} \log 7=$ $a$ dan ${ }^{2} \log 3=b$. Kemudian mereka juga bisa menjabarkan bentuk ${ }^{6} \log 14$ dengan sifat ${ }^{a} \log b=\frac{{ }^{c} \log b}{{ }^{c} \log a}$. Pada soal nomor 5, subjek C juga telah mengerjakan dengan benar, sudah paham mengenai perkalian logaritma dan memahami sifat logaritma yaitu ${ }^{a} \log b . \quad{ }^{b} \log c={ }^{a} \log c$ dan $a^{c} \log b^{d}=\frac{d}{c} \quad a \log b$.

Menurut hasil wawancara saat ditanyai kenapa bisa salah dalam menjawab, semua subjek menjawab bahwa mereka lupa dan tidak paham akan sifat-sifat logaritma. Mereka juga tidak paham sifat logaritma mana yang harus dipakai pada soalsoal tersebut, karena setiap soal memakai sifat logaritma yang berbeda dan juga sifat logaritma ada banyak jadi mereka lupa dan susah memahami. Peneliti sengaja memberikan soal-soal yang mencakup semua sifat pada logaritma sehingga bisa tahu sifat mana yang subjek tidak paham dan tidak mengerti. Ketidaktahuan subjek tentang sifat logaritma ini termasuk pada kesalahan konsep. Akibat tidak tahu sifat logaritma yang akan digunakan lalu subjek menjadi salah karena mengarang cara-cara yang digunakan. Ada juga subjek yang salah dalam menghitung akibat tidak teliti. Saat diberitahu oleh peneliti bahwa jawabannya salah lalu subjek menghitung dan meneliti kembali hasil pekerjaannya dan menyadari bahwa dia salah hitung padahal cara yang digunakan sudah benar. Kesalahan seperti itu termasuk kesalahan teknik. Kemudian banyak dari jawaban subjek yang salah karena tidak menggunakan langkah pengerjaan. 


\section{Kesimpulan}

Berdasarkan hasil penelitian dan pembahasan dapat diambil kesimpulan yaitu kesalahankesalahan yang dilakukan oleh siswa adalah karena 1) siswa tidak memahami soal yang ada, 2) tidak memahami konsep materi yang ada, 3) ketidaktelitian dan ketidakcermatan saat menghitung, 4) tidak memakai semua data yang ada pada soal bahkan kadang melewatkan data yang penting karena siswa sudah terlalu bingung dan tidak paham dengan soal yang ada, 5) mengerjakan secara langsung tanpa menggunakan langkahlangkah pengerjaan karena siswa hanya menerawang cara-cara pengerjaannya pada otak mereka. Berdasarkan hasil wawancara didapat bahwa saat siswa melihat soal lalu tidak memahami soal tersebut, mereka cenderung malas untuk mengerjakan dan berhenti mengerjakan ditengah jalan lalu tidak menyelesaikan jawaban hingga akhir bahkan tidak mengerjakan soal itu sama skali. Ada juga yang salah menggunakan sifat logaritma karena bingung terlalu banyak sifat logaritma yang ada.

Adapun saran bagi peneliti lain, hendaknya penelitian ini dapat dijadikan acuan bagi penelitian selanjutnya agar dapat berkontribusi dalam upaya meningkatkan mutu dan kualitas pendidikan. Saran bagi guru, kiranya dengan adanya penelitian ini dapat memperbaiki dan mengembangkan sistem pembelajaran, serta lebih menekankan kepada siswa sifat-sifat logaritma mengingat sifat logaritma yang banyak dan siswa mengalami kesalahan memilih sifat dalam pengerjaan soal. Ada baiknya sering dibuat kuis kecil tentang sifat logaritma supaya siswa lebih hafal dan lebih paham tentang sifat logaritma.

\section{Referensi}

Amir, M. F. (2015). "Analisis Kesalahan Mahasiswa PGSD Universitas Muhammadiyah Sidoarjo dalam Menyelesaikan Soal Pertidaksamaan Linear.”
Blanco and Garrote. "Difficulties in Learning Inequalities in Students of First Year of PreUniversity Education in Spain"

Ciltas dan Tatar. (2011). "Diagnosis Learning Difficulties Related to the Equation and Inequality that Contain Terms with Absolute Value"

Ischak dan Warji. (1987). "Program Remedial dalam Proses Belajar Mengajar”. Yogyakarta: Liberty

Mulyadi. (2010). Diagnosis kesulitan belajar. Yogyakarta: Nur Litera.

Newman, M. A. (1977). “An analysis of sixth-grade pupils' errors on written mathematical tasks. Victorian Institute for Educational Research Bulletin".

Riedesel, Scchwart, dan Clement. (1996). "Teaching Elementary School Mathematic". Boston: Allyn and Bacon.

Sugiyono. (2014). "Metode Penelitian Pendidikan". Bandung: Alfabeta.

Uni, H. B. (2009). "Model Pembelajaran (cetakan IV)". Jakarta: Bumi Aksara.

Widodo, S. A. (2013). “Analisis kesalahan dalam Pemecahan Masalah Divergensi Tipe Membuktikan pada Mahasiswa Matematika". Jurnal Pendidikan dan Pengajaran. 